\title{
POSTHUMAN REVISIONS OF ORGANIC FORM IN POETRY
}

By Michelle Niemann (University of Wisconsin-Madison)

What does the posthuman have to do with contemporary revisions of organic form in poetry? Do these revisions of organic form have anything to offer to posthumanist theory? Given that literary organicism, in its most familiar Romantic and New Critical forms, evokes holism, aesthetic closure, and the humanizing function of poetry, this pairing seems an unlikely one. Donna Haraway, in the well-known "Cyborg Manifesto" that launched one strand of posthumanism, sees political promise in the cyborg precisely because it escapes the naturalizing logic of organic tropes: "The cyborg skips the step of original unity, of identification with nature ... The cyborg would not recognize the Garden of Eden; it is not made of mud and cannot dream of returning to dust" (Haraway 1991, 51). But can decay figure otherwise than as a reactionary reinscription of origins? I argue that Jed Rasula and Frank Bidart, from two disparate poetic lineages, both use figures of decay—even posthumous decay—- to revise literary organicism.

Since posthumanism seeks to de-naturalize the category of the human, it can perhaps help us explore to what extent Rasula and Bidart, even though they do not reject organic tropes entirely, call into question humanist claims about the poet as natural genius and poetry as a moral force. Jed Rasula's This Compost: Ecological Imperatives in American Poetry (2002) and Frank Bidart's long poem "The Third Hour of the Night," which appeared in Star Dust (2005), both use the organic processes of composting, eating, and decay as metaphors for writing poetry and making art. In casting the poem as a decaying organism rather than a growing one, Rasula and Bidart do not simply seal the dust-to-dust closed circle whose apocalyptic yearnings Haraway decries; rather, their 
work figures decay as part of an uneven, never-finished process of de-creation and recreation whose remnants and concretions constitute culture.

While Rasula and Bidart figure poetic composition as a process of collaborative or violent re-working, Romantic organicism emphasizes the autonomy of art; it understands the poem, and sometimes the poet's genius, through the metaphor of an organism whose internal principles direct its growth. According to Samuel Taylor Coleridge's famous definition, "organic form ... is innate; it shapes as it develops itself from within, and the fullness of its development is one and the same with the perfection of its outward form" (Coleridge 1991, 471). Form and content are inextricably linked here; the poem fulfills the shape implicit in it. Murray Krieger, a recent defender of organic form, writes that "the center of organicism" is "its claim that the regulative principle of growth in the created entity must be internally derived and internally directed" (Krieger 1989, 5). Paul de Man's critique of New Critical organicism links aesthetic closure to a totalization of meaning with negative political implications. De Man argues that American New Critics "pragmatically entered into the hermeneutic circle of interpretation, mistaking it for the organic circularity of natural processes" (DeMann 1989, 29). Though critics cannot close the hermeneutic circle by constructing an "ideal commentary" that "reach[es] the text itself," in their attempt to do so, they treat poems as if they were whole, autonomous "natural object[s]" $(30,24)$.

While literary critics who follow de Man tend to dismiss organicism for its politically retrograde tendencies to see poems as totalizing and timeless structures of meaning, a wide variety of twentieth-century American poets, from traditionalists to experimenters, have understood poetic form in organic terms. While Cleanth Brooks, 
from the New Critical end of the spectrum, advocated organic form in a major teaching anthology called Understanding Poetry, Charles Olson, a Black Mountain poet who took up the techniques of Ezra Pound's Cantos, declared in "Projective Verse," in all capital letters, "FORM IS NEVER MORE THAN AN EXTENSION OF CONTENT"-an organicist claim if there ever was one (Olson 1966, 16). Brooks' version of organicism promotes reverence for canonical poems read as self-contained and perfected (he analyzes poems by Shakespeare and Yeats in the section on the "Organic Nature of Poetry," for example), (Brooks and Warren 1960, 16-20). Olson's assertion, on the other hand, functions as an organicist call to throw off formalist constraints.

I argue that Rasula and Bidart participate in a "new organicism" that shifts organic form's metaphoric accent from growth to decay. While Rasula investigates poems-as-ecosystem in what he calls the "compost library" of cultural inheritance, Bidart explores the dark underside of organic metaphors for art through the gruesome monologue of a sorcerer who violently remakes a woman's living body. Recently, Timothy Morton has used the term "new organicism" to describe "'emergent' forms" that "employ external, mechanical, or stochastic (random) processes of composition" (Morton 2007, 189). Morton's analysis draws out the irony of using "some essentially algorithmic process" to create forms "compared with the growth of flowers or the spread of clouds:" it shows how "the natural world is thoroughly automated, mechanical, and repetitive" (191). While Morton shows how this kind of new organicism inverts the "old organicism" (190-191), I suggest that we use the term "new organicism" more broadly to designate contemporary attempts to revise organicism in other ways - not only by 
refiguring organic form to emphasize decay, but also by changing the organic metaphor, as, for example, in Oni Buchanan’s rhizomic “Mandrake Vehicles” in Spring (2008).

Because Rasula and Bidart work from quite different poetic communities and affiliations, the resonances between their efforts show how a concern for revising organic form cuts across varied poetics. Rasula focuses in This Compost, on the Black Mountain lineage of experimental poetry that includes Charles Olson, Robert Duncan, and Robert Creeley. Bidart, on the other hand, places himself in a more mainstream lineage, though he is eclectic in his declared affiliations, citing Allen Ginsberg alongside T. S. Eliot, for example (Bidart 2006, 253-254). While Bidart was a student of Robert Lowell and edited Lowell's Collected Poems, Rasula, in The American Poetry Wax Museum (1996), uses Lowell as his primary example of the way in which the twentieth-century American poetry establishment makes poems into frozen display objects and poets into wax figures whose biographies are better known than their works. If Bidart, unlike Rasula, associates himself with a mainstream, confessional tradition, he also unsettles that tradition. Bidart speaks of the individual poet as a heroic maker of poems, but at the same time, he writes dramatic monologues, a form that has long interrogated the solipsism of the Romantic, lyric speaker by placing that speaker in an implied social context.

While Rasula collages the lines of multiple poets to enact his concept of the "compost library," Bidart presses on the limits of organic form through a speaker whose story is designed to repel us. Despite their differences, Rasula's This Compost and Bidart's "The Third Hour of the Night" take part in a kind of new organicism that emphasizes the poem-organism's susceptibility to decay rather than its capacity for growth. Both Rasula and Bidart figure the poem as a decaying organism; both see poetic 
composition as a process of long-term compost or consumption rather than as the solitary growth of a discrete poem-organism. As we will see, both stress what Rasula calls the "nutritive sensibility, envisioned as an environmental continuum encompassing biotic as well as cultural communities" (Rasula 2002, 7).

In his preface, Rasula explains the book's unconventional method: “This Compost practices what it preaches in that most of the citations of poetry are not identified in the text, but blended into polyphonic configurations" (Rasula 2002, xii). Rasula's collage method does not produce jarring juxtapositions, but effaces authorship by smoothing together quotations that circle around a particular set of concerns. ${ }^{1}$ It thus becomes a way of showing how disparate poets think through questions they hold in common. On a single two-page spread, for example, Rasula has assembled lines by a wide and eclectic range of poets: Charles Olson, Adrienne Rich, George Oppen, Robert Penn Warren, Ed Dorn, Philip Lamantia, Hart Crane, Robert Creeley, John Clarke, Muriel Rukeyser, and Kenneth Irby (32-33). By freeing bits of poems from their authors' names and mixing them here, Rasula enacts the process of decomposition and re-composition which, according to his argument, constitutes the "compost library" of cultural inheritance (13). Rasula argues that poetry is "ecology in the community of words" (7), but he does not simply use compost as a metaphor for the processes by which poets remake their cultural inheritance; the metaphor of the compost library becomes literal when Rasula turns to the material archive. He argues that, in the nineteenth century, the discovery of the Rosetta stone and of ancient Mesopotamian texts fertilized the American Renaissance (13-14). This context, Rasula argues, sheds light on the material valences of Henry David

\footnotetext{
${ }^{1}$ Lynn Keller, personal communication, March, 2009.
} 
Thoreau's comment, in his Journal for March 16, 1852, that “Decayed literature makes the richest of all soils" (Thoreau 1992, 392). Through his concept of the compost library, Rasula critiques organicism's conventional assertion that the poem is a whole, perfected object even while he still emphasizes organic processes as both the metaphor and the matter of poetic compost.

While Rasula's compost brings ecological, archival, and psychological processes into metaphorical and material relationship with each other, Bidart literalizes the metaphor of organic form through his juxtaposition of a monologue by the sculptor Benvenuto Cellini with a monologue by a sorcerer who "sculpts" a living woman's body in "The Third Hour of the Night." Cellini's monologue focuses on his struggles with his patrons, the Medici family, his violent acts and inclinations, and his art making. When Cellini averts imminent disaster in the process of pouring bronze into a mold and succeeds in casting his statue of Perseus, he speaks of the statue as resurrected. But the material realization of this artwork does not fulfill a prior and primary concept: Cellini says of his statue of Perseus, "if he ever / was to exist as idea, he must first exist as matter:-" (Bidart 2005, 66-7). Cellini's monologue about casting a human form in bronze is followed by the monologue of a sorcerer whose artistic material is a living woman.

The sorcerer's monologue highlights the violence latent in a metaphoric understanding of the artwork or poem as an organism. The sorcerer hits the woman "between the eyes with my hatchet," and then in a gruesome sequence, rapes and disembowels her with the "killing stick" he has just made:

With my thumb over the end of the killing stick 
I jabbed her Mount of Venus until her skin pushed

back up to her navel. Her large intestine

protruded as though it were red calico. (Bidart 2005, 75)

The sorcerer continues until he "touched her heart," meeting the paradox that, "Once you reach what is / inside it is outside." Her "spirit," the sorcerer tells us, "went into [his] heart" when he "pushed the killing stick // into her heart."

After he appropriates her spirit, however, the sorcerer begins to remake her. $\mathrm{He}$ puts "live ants" on her, who "bite her skin until her skin moved by itself // downward from her navel and covered her bones" (Bidart 2005, 76). Then, in an act that recalls Cellini's casting of his statue of Perseus, the sorcerer fills the woman's body with mud:

Then I took some dry mud and put my sweat and her blood in the dry mud and warmed it over a fire. Six or eight times

I put the blood and sweat and mud inside her uterus until there was no trace of her wound or what I had done.

I was careful none of her pubic hair was left inside her vagina for her husband to feel.

The sorcerer's monologue, set to parallel Cellini's monologue on making immortal (bronze) works of high caliber, should give us pause about attributing redemptive or humanizing qualities to art. Art, here, is both an act of rape and what hides that act; it is a way of killing and of appropriating the spirit of the one killed. The sorcerer remakes and revives the woman, but only to exercise over her the godly power of declaring the time of her death: "You will live / two days. One day you will be happy. The next, sick" (Bidart 2005, 77, emphasis in the original). 
The sorcerer's monologue casts a gruesome light on the closing lyrical section that immediately follows it. In this section, an unspecified lyric speaker meditates on the compulsion to make art; the speaker likens inheriting cultural products to eating, and making art to "becoming food."

Infinite the forms, finite tonight as I find again in the mirror the familiar appeaseless

eater's face

Ignorant of cause or source or end in silence he repeats

Eater, become food

All life exists at the expense of other life

Because you have eaten and eat as eat you must

Eater, become food

unlike the burning stars

burning merely to be

Then I ask him how to become food

In silence he repeats that others have

other fates, but that I must fashion out of the corruptible

body a new body good to eat a thousand years

Then I tell the eater's face that within me is no sustenance, on my famished

plate centuries have been served me and still I am famished

He smirks, and in silence repeats that all life exists

at the expense of other life

You must fashion out of the corruptible

body a new body good to eat a thousand years

Because you have eaten and eat as eat you must ignorant of cause or source or end 
drugged to sleep by repetition of the diurnal round, the monotonous sorrow of the finite,

within I am awake

repairing in dirt the frayed immaculate thread forced by being to watch the birth of suns

This is the end of the third hour of the night.

(Bidart 2005, 79-80, emphasis in original)

Bidart not only evokes the Eucharist, but also enacts the "new body" of art as a remaking of cultural inheritance by himself remaking a line from "Howl" in which Ginsberg speaks of "the absolute heart of the poem of life butchered out of their own bodies good to eat a thousand years" (Ginsberg 1959, 20).

The fact that this section follows the sorcerer's monologue gives a cannibalistic cast to this image of Eucharistic feeding. Art, here, is not immortal but consumable, and the insistence that "all life exists at the expense of other life" results in a dark take on artmaking as composting. At the same time, the lyric speaker "repair[s] in dirt the frayed immaculate thread" (Bidart 2005, 80): art is both a material "thread" that can "fray" and an "immaculate thread," a metaphoric umbilical cord that connects the living to the dead not through birth or biology, but through the materiality of cultural inheritance. The speaker, stuck in the "monotonous sorrow of the finite" and "forced . . . to watch the birth of suns," must "repair" the thread of art in "dirt" - that is, the mortal speaker must seek continuity in material terms. The speaker must connect the dead and the unborn by remaking an inheritance from the dead with the only materials available_- "dirt" and the 
speaker's own "corruptible body." Moreover, this fashioning is done at the instigation of the posthumous. Because the "eater's face" that the speaker confronts in the mirror speaks Ginsberg's words, it is at once the speaker's own face and that of the dead Ginsberg. Thus the dead from whom we inherit a cultural world and the self as soon-tobe-posthumous, a famished eater in a corruptible body, insist that we "become food" through artistic creation.

Rasula also speaks of his compost library in terms of the posthumous-which he sets in apposition with the posthuman: "The post-human-the posthumous Homo Sapien — passes from cosmos to chaos. But chaos has always been with us ... The subterranean transmissions of composting poetry have been compacted in the compost library, where biodegradable thinking occurs, where we can conceivably speak of an 'ecology of consciousness'” (Rasula 2002, 43). For all their differences, Rasula and Bidart are similar in that they insist that organic form in poetry must reckon with the posthumous - with the organism as dying and decaying. While Language Poetry, for example, avoids the Romantic humanism implicit in organic form by rejecting organicism altogether, both Bidart and Rasula recuperate organic form. For Bidart, the organic form becomes Eucharistic grotesque. In contrast, Rasula recuperates organic form by moving it into a collective, ecosystemic register that sees decomposition as part of composition. If the new organicism interrogates humanism, it perhaps does so most provocatively through its refigurations of the posthumous. 
Works Cited

Bidart, Frank. "A Cross in the Void." The Poem That Changed America: "Howl" Fifty Years Later. Ed. Jason Shinder. New York: Farrar, Straus and Giroux, 2006. 246254.

—. Star Dust. New York: Farrar, Straus and Giroux, 2005.

Brooks, Cleanth and Robert Penn Warren. Understanding Poetry. Third Edition. New York: Holt, Rinehart and Winston, 1960.

Buchanan, Oni. Spring. Urbana: University of Illinois Press, 2008.

Coleridge, Samuel Taylor. "Shakespeare's Judgment Equal to His Genius." Critical Theory Since Plato. Ed. Hazard Adams. Rev. ed. New York: Harcourt Brace, 1991.

De Man, Paul. "Form and Intent in the American New Criticism." Blindness and Insight: Essays in the Rhetoric of Contemporary Criticism. Second Edition, Revised. Minneapolis: University of Minnesota Press, 1983. 20-35.

Ginsberg, Allen. Howl and Other Poems. The Pocket Poet Series Number Four. San Francisco: City Lights Books, 1959.

Haraway, Donna J. “A Cyborg Manifesto: Science, Technology, and SocialistFeminism in the Late Twentieth Century." Simians, Cyborgs, and Women: The Reinvention of Nature. New York: Routledge, 1991. 149-181.

Keller, Lynn. Personal communication. March 2009.

Krieger, Murray. A Reopening of Closure: Organicism Against Itself. The Wellek Library Lectures at the University of California, Irvine. New York: Columbia University Press, 1989.

Morton, Timothy. Ecology without Nature: Rethinking Environmental Aesthetics. Cambridge, MA: Harvard University Press, 2007.

Olson, Charles. "Projective Verse." Selected Writings of Charles Olson. Ed. Robert Creeley. New York: New Directions, 1966. 15-26.

Rasula, Jed. This Compost: Ecological Imperatives in American Poetry. Athens: University of Georgia Press, 2002. 
Thoreau, Henry D. Journal. Vol. 4: 1851-1852. Ed. Robert Sattelmeyer, Leonard N. Neufeldt, Nancy Craig Simmons. Princeton, NJ: Princeton University Press, 1992. 